DOI: https://doi.org/10.32839/2304-5809/2020-4-80-44

UDC 821.751

Timofieieva Viktoriia

Dnipro O. Honchar National University

\title{
THOMAS CHATTERTON AND JAMES MACPHERSON. THE GREAT HOAXERS
}

\begin{abstract}
Summary. This article discusses how Chatterton's and Macpherson's hoaxes problematises the representational view of literature regarding theories of forgery. Perhaps the hardest thing of all to forge is provenance. A forger cannot alter the past as he can alter documents or material objects, and thus it is that forgeries often break down on provenance - the establishment of a chain of evidence (location, ownership, documentary record) that will lead securely back to the alleged source. Some discussions about the world of literature are among other things centred on the subject of artistic mimesis. This is meant in the sense that there is a close and special relationship between art and reality. This in turn quickly develops into a discussion about the role that authenticity and authorship have in the significance of a piece art or literature. This is done in a way that relies heavily on the reader's knowledge of the world of literature and literary theory. It also highlights the narrative strategies and techniques of their works which result in demystifying the text's meaning-granting process; hence, problematisation of reality.
\end{abstract}

Keywords: Chatterton, Macpherson, hoax, forgery, fraud, fake, reality.

Тімофеева В.C. Дніпровський національний університет імені Олеся Гончара

\section{ТОМАС ЧАТТЕРТОН I ДЖЕЙМС МАКФЕРСОН. ВЕЛИЧНІ МІСТИФІКАТОРИ}

Анотація. В цій статті обговорюеться, як мистифікації Чаттертона та Макферсона піднімають питання про репрезентативний погляд на літературу Великобританії. Містифрікація («Поеми Роулі»), автором якої був Чаттертон, «цілком відповідала романтичному сприйняттю середньовіччя, що починало формуватися у XVIII ст., а також явищу «передромантичної містифікації», найбільш яскравим прикладом якої став «Оссіан» Макферсона («Твори Оссіана»). Така проекція дозволяе простежити наративну стратегію та авторські принципи оповіді, які обумовлюють процес демістифікації історії, про яку йдеться, а 3 тим проблематизацію реальності. Можливо, найважче з усього, що підробити - це походження. Фальсифікатор не може змінити минуле, як він може змінити документи або матеріальні об'єкти, і таким чином, підробки часто порушують походження - створення ланцюжка доказів (місцезнаходження, право власності, документальний фрільм запис), що безпечно приведе до передбачуваного джерела. Сама витончена містифрікація - містифікація par excellence - пов'язана зі створенням детально розробленої біографії вигаданого автора і включенням ціеї біографії в реальний історико-культурний контекст. 3 огляду на правильну атмосферу, а іноді спритний вибір, підробка іноді може довго залишатися непоміченим. Рідко, проте, це йде несподівано, і коли це відбуваеться, в гру вступають особисті фрактори. Ті, хто вперше повірив у його справжність, не хочуть змінювати свою думку через страх втрати довіри (а іноді і фрінансових втрат); та з іншого боку це може викликати підозри зацікавлених осіб що прагнуть до істини, наприклад, через заздрість або суперництво. У розгорнутій багаторівневій побудові «середньовічних" поем Джеймса Макферсона і Томаса Чаттертона, що виявляють ознаки різних часових структур, відбувається відлік міфропоетичного часу. Саме цим часом продиктований своерідний поетичний стиль «Творів Оссіана» $\mathrm{i}$ «Поем Роулі» і визначена їх основна текстова характеристика. В даних творах задіяні масштабні шари підсвідомості не тільки поетів Нового часу, а й опосередковано - «справжнього» творця творів, відтвореного (у Дж. Макферсона) або створеного (у Т. Чаттертона) поетичною уявою цих найвідоміших представників «великого періоду літературної містифікації» у Великобританії.

Ключові слова: Чаттертон, Макферсон, містифікація, підробка, реальність.

The aim of this article is the study of

1 Chatterton's and Macpherson's hoaxes on the example of their works.

The "spectre" of this great plagiarists, whose method we will study in more detail later on, appears to be of the greatest relevance in the recreation and representation of the historical events of the past we are offered in the article.

The question of representation is inherently related to the status and nature of literature itself. Far be it from me to give a definition of literature, unavoidably a problematic and questionable task. The debate has long been established and it is still far from reaching a definite conclusion.

The focus of representation here is Thomas Chatterton, "the greatest plagiarist or the greatest poet" is the same as representation of his literatural predecessor James Macpherson. This representation does not limit itself to just one system or field but expands and turns to be a representation of them in history, biography and art.

In the field of classical antiquity, forgeries are frequent. Some go back to antiquity itself, others are very recent; some have proved very hard to detect, others are so thinly disguised that they might more properly be called frauds, fakes, or even hoaxes. Thus the series of biographies of emperors usually called the Augustan History, universally believed genuine until the end of the nineteenth century, is now recognized as the work of a "frivolous impostor" (R. Syme, Ammianus and the Historia Augusta (Oxford: Clarendon Press, 1968) 4: cf. Ch. XXI, "Other Frauds").

Among the leading English poets of the third quarter of the XVIII century, of course, you can name those whose fame was literary hoaxes: James Macpherson and Thomas Chatterton. Their work falls on the $1760 \mathrm{~s}$, when, with increasing interest to 
everything Gothic, the Celtic revival (1750-1800) the most intensively takes place. By this time, despite the "enlightening" calls of the adepts of classicism, connoisseurs and connoisseurs of ancient art (J. Addison) to "avoid the Gothic taste" and focus on the ancient classics to bring up a genuine good literary taste ("Spectator", No. 409), Gothic culture captures almost all spheres of artistic activity: music, literature, painting, architecture, landscape gardening art. There is a "rehabilitation" of "barbaric" times in the eyes of the Englishman of that time, brought up on his adoration of classical literature. It is noteworthy that the letters in the Gothic font, which the old Bible was printed, became a window into the world of books for Thomas Chatterton - before that he was considered as close-sighted, since in comprehension he was desperately behind peers, having managed to remember only two letters of the alphabet. According to the mother's recollections, the son's "insight" occurred when he was six and a half years old: he watched her tearing apart the old books of her deceased husband, and then, in her words, "fell in love" with the illuminated letters of old folios [1, p. 144]. With the help of his sister, he quickly mastered the letter from the initial letters of the poems (letter dated September 22, 1778 to the poet Mary Newton's sister, Sir G. Croft, author of the controversial book Love and Madness (1780), a large part of which devoted to the literary hoaxes of T. Chatterton and J. Macpherson) [2, p. 460; 7]. Since then, the medieval world that opened to T. Chatterton has become his main reality, replacing and almost completely obscuring everyday life. Already at seven or eight years old, he spent hours sitting at the old books and manuscripts found in St. Mary's Church in Redcliffe, remaining, according to his relatives, as if in a state of trance; from time to time his reading was suddenly interrupted by rampant sobs. (Decades later, Walter Scott explains the phenomenon of T. Chatterton as "split personality" of the poet [3, p. 197-200].) It is not surprising that, along with the "medieval" poetic works, Thomas Chatterton also writes prose "Proclamations", which in 1769 he sends to the Bishopric vicar J. Ketkotte, trying to pass them off as genuine church documents of the 15 th century. On behalf of a certain A. B., the editor of "Gentleman's Magazine" T. Chatterton also sends a fragment of a sermon supposedly belonging to the pen of the same Thomas Rowley [2, p. 64-66]. In literary magazines, he sends his "medieval" poems: "Ethelgar", "Kenrick", "Cerdick", "Godred Crovan", "The Hirlas I", "Th e Hirlas II", "Gorthmund", "Cutholf” (March 1769 - Summer 1770), designating the first four poems as "translations from Saxon", and the poem "The Hirlas I" - as "translating from Old English" [4, p. 417; 10, p. 273-284]. These passages were published in 1803: a three-volume collected work, prepared by R. Southey and J. Cottle, was published in London and Bristol, the poet's hometown, 12 and reviews appeared in the Edinburgh Review (Vol. 4), "The London Quarterly" (Vol. 41), "The Quarterly" (Vol. 150). This part of Thomas Chatterton's creative heritage is still poorly understood. Modern scholars have traditionally viewed these works more like parodies of Ossian poetry. Donald Taylor, author of a comprehensive study, The Art of Thomas Chatterton. Experiments in an imaginary story", trying to identify the degree of correlation of these poems, puts them in a chapter called "Ossianic" [5, p. 273]. Such an identification seems to us insufficiently accurate, since the medieval style reproduced by T. Chatterton in the poems designated by him as "translations from Saxon" is significantly different, for example, from the style of the poem "The Hirlas I", translated, according to the author's directive, from Old English [2, p. 46] and ascending, according to the correct definition of D. Taylor, to Welsh poetry [10, p. 279-280]. In these works, the "medieval" style of T. Chatterton discovers various temporal and spatial characteristics related to the almost thousand-year history of the Middle Ages in Albion, and requires a separate detailed study. Thomas Chatterton also owns a correspondence between the invented poet Rowley and the great poet of the late Middle Ages D. Lidgate. "The following lines," explains Chatterton, "were created by John Lidgate, a priest from London, and sent in response to the previous Ella's Song": Now Rowlie ynne these mokie dayes Lendes owte hys sheenynge lyghtes, And Turgotus and Chaucer lyves Ynne ev'ry lyne he wrytes" ("John Ladgates Answer", 11. 17-20) [6]. T. Chatterton's "original" stanzas underwent significant changes in numerous editions of his works, which is quite obvious when comparing them, for example, with the edited "modernized" version proposed in a two-volume full collection of his works prepared by D. Roberts in 1906. Such a "revision", of course, could not but affect the sonority of Chatterton's "medieval" verses, and their visual reception: Now Rowlie in these mokie days Lends out his shining lights, And Turgotus and Chaucer lives In every line he writes. ("John Ladgates Answer", 1l. 17-20) [7, p. 89]. According to the testimony of J. Thistletveit, who spoke with the poet from early childhood, the original stanzas of the poem "The Death of Sir Charles Boden" (The Death of Syr Charles 13 Bawdin), which he had read in manuscripts in 1768 , were so distinguished by "wonderful simplicity, liveliness and elevation" that forever engraved in memory. The stanzas published by T. Terwitt in 1777 are different: they are replete with later interpolations, which, according to J. Thistletveit, were made "out of ignorance" by T. Chatterton in order to improve the poem with the help of the glossary Chaucer and English Skinner's etymological dictionary (Etymologicon Linguœ Anglicanœ) [2, p. 472-473].

In a detailed multi-level construction of Ossianic poems that reveals the signs of various time structures, the countdown of mythopoetic time occurs, which, unlike historical time, is discontinuous, of course, and reversible. Its properties are determined by the recurrence of sacred events, which is why the "ancient legends of the deep" in "The Woks of Ossian" look more convincing; the main events unfold in two time plans, and individual episodes lose their connection with the whole, attention is focused on secondary objects, which are almost not connected with the outline of the narrative. A revealing passage from Book II of Fingal, the main action of which (set out on several pages) revolves around the story of Cuchullin about how he killed his close friend Ferd, the chief of a hundred hills, the noble son of Damman, tall and fair he was like the rainbow of the hill. This story is the most im- 
portant in the Irish epic "Abduction of a bull on $\mathrm{Ku}$ alng". However, in "Fingal" by J. Macpherson, he was only given a page: he was imprisoned in the stylistic technique of ring repeating the most penetrating lines of the poem, where Cuchullin's deep remorse for his deed sounds, according to an ancient poetic tradition, from a third person: "From that fateful day, when he defeated a friend, his right hand was not happy." Compare with the final line of this snippet: Unhappy is the hand of $\mathrm{Cu}$ chullin since he slew his friend. $\rightarrow$ Unhappy is the hand of Cuchullin since the hero fell [8, p. 69-70]. Listening to the sad story of Cuchullin, the leaders tested by the battles acknowledge that few of the heroes was sent such a curse - the punishment for defeating (even in honest martial arts) a friend whom he "loved as himself" [8, c. 33]. The story of Cuchullin is followed by the no less woeful tale of Komala, the "leader of hundreds of hills," and his beloved Galvina, whom he accidentally shot down with an arrow, which was related to the more ancient times by Elder Karil, after which he sought death on his battlefield [8, p. 34]. In the "medieval" poems of J. Macpherson, in which the deeper layers of bardic poetry are recreated than those of T. Chatterton, the mythopoetic time is characterized by a combination of signs and will take two deeply different temporal structures: mythical and verbal-artistic - folklore and literature. The famous Pushkin verse from "Ruslan and Lyudmila" is a retelling of the words of Cuchullin at the beginning of "Fingal" (Second Book): "Pleasant are words of the song, said Cuchullin, and lovely are the tales of other times" [8, p. 73]. The key feature of mythopoetic time in "The Works of Ossian" and "Rowley's Poems" is the transformation of empirically or historically possible in the world and in history into a reproduction of eternal prototypes (recognizable archaic motifs). For J. Macpherson, the lyric-epic legend unfolds in such a way that the main characters and their statements, as well as the interpretation of these statements by the storyteller (a bard reproducing the "ancient legends of the deep"), are a variation of the eternal "prototypes". Therefore, in the poem "Karik-Tour", the spirit of Lod appears before Fingal, who is given the opportunity to decide the outcome of the battle on the military fields. The ghost ominously bends over Fingal, demanding to leave his possessions, to which the king fearlessly declares: "...will the sons of the wind frighten King Morven? No, he knows the impotence of their weapons" [8, p. 122]. The king pierces with his sword an ominous ghost that dissolves in the air, "like a pillar of smoke rising from a half-extinguished furnace when his stick is cut by a youth" [8, p. 122]. In the notes to the poem, J. Macpherson notes that the circle of Lod at the top of the rock is the place of worship of the Scandinavians, who believe that Lod is one of the many names of the great Odin [8, p. 461]. The song of the first poem of the Cath-Loda also causes reminiscences from the song tales of Edda; it ends with a description of the air palace of Kru-loda, the "home of shadows", which is invariably associated with Valhalla, the air castle of the Scandinavian God of the gods Odin and the Einherians, soldiers who fell in battle honored for heroic death in a heavenly castle. The description of the Celtic palace of Kru-Loda is more figurative and picturesque than the eddic descriptions of Valhalla: the Kru-Loda tribe appears as "a string of shadowless formless shades" (a ridge of formless shades); the roofs of the terrible habitation of Kru-Loda are marked by night lights; with his own hands (in Valhalla, this role, as you know, is assigned to the Valkyries) "extends the sonorous cup to those who shone in battle; his shield rises, a crust of darkness" [8, p. 309]. The description of the Celtic palace is interrupted at a glance with the appearance of the white handed Conban Karglas ... Note that the Celtic bards often deliberately interrupted the story in the middle of the word, while inserting individual fragments and appeals - duän (song).

Mythopoetic time is dictated by a peculiar poetic style of Ossian legends, which in rhythmodynamic panoramic lighting can be represented as many predominantly horizontal lines of various lengths and emotional stress. The development of the main topic is facilitated by the appearance of a number of side effects, and thus the narrative is multi-motivational, and completely new relationships for that time are established between the main and side topics. This happens due to the appeal to the origins of national poetry, to world mythology, to the folk traditions of his country and attempts to revive them. Thus, it is logical that the "medieval" poems of J. Macpherson, like the "Rowley Poems" by T. Chatterton, are in sharp contrast with the poetry of the early Enlightenment, oriented primarily to antique samples, for which the horizontal idea of a poem that flows linearly through time is generally indicative. Moreover, it is important to note that the poetic style of individual "Rowley Poems" dates back not so much to the late Middle Ages (XV century), when, according to the artistic imagination of T. Chatterton, the poet-priest Thomas Rowley lived and worked, and to more ancient times - to the beginning Norman invasion (XI century). So, the epic poem "The Battle of Hastynges" (1768) was created by T. Chatterton on behalf of Tirgot (died in 1115), Bishop Durham, author of "Life of St. Margaret Queen of Scot". According to the artistic design of Thomas Chatterton, this poem was translated by Thomas Rowley four centuries after the "creation". The plot of "The Battle of Hastings" (two versions of the poem are known) refers to the most crucial time for Albion and for the national language, when native speakers of French, culture and political structure came to Britain. Thomas Chatterton was one of the first to point out the phenomenon of the "medieval" poetic language of Thomas Chatterton: "His works are written in pure English. He has neither French idioms, nor French unchanged particles that Chaucer has - he has primordial English idioms in English words" (D. Keats letter to D. G. Reynolds dated September $22,1819)[9$, p. 380]. D. Keats is convinced that this language should be preserved, because it is unique: "this northern dialect, which was influenced by the inversions and intonations of the Greek and Latin languages. The purest English language ... this is Chatterton's language", an outstanding romantic poet comes to this conclusion (see Keats letter to his brother George Keats on September 17, 1819) $[9$, p. 418$]$. In the preface to the poem "Endymion" dedicated to Thomas Chatterton (Endymion: A Poetic Romance, 1818; author's definition of the gen- 
re is poetic romance). D. Keats calls him the most English of English poets after Shakespeare. Thus, in the detailed multi-level construction of the "medieval" poems by J. Macpherson and T. Chatterton, which reveals the signs of various time structures, the countdown of mythopoetic time occurs. This time was dictated by the peculiar poetic style of "Works of Ossian" and "Rowley Poems" and their main textual characteristic is defined. These works involve large-scale layers of the subconscious not only of poets of the New Age, but also indirectly - the "true" works of the artist, recreated (by J. Macpherson) or created (by T. Chatterton) by the poetic imagination of these most famous representatives of the "great period of literary mystification" in Great Britain.

\section{References:}

1. The Dictionary of National Biography: in 22 vols / ed. by L. Stephen, S. Lee. London: Oxford University Press, 1921. Vol. 4. 1392 p.

2. The Works of Th omas Chatterton: in 3 vols. London: Printed by Biggs and Cottle, Crane Court, 1803. Vol. 3. 528 p.

3. Vershinin I. V. Chatterton. SPb.: Knizhnyiy dom, 2001. 275 s.

4. Bronson B. H. Chattertoniana // Modern Language Quarterly. 1950. Vol. 11, no. 4. P. 417-424.

5. Taylor D. S. Th omas Chatterton's Art. Experiments in Imagined History. Princeton: Princeton University Press, 1978. 343 p.

6. Songe To Aella, Lorde Of Th e Castel Of Brystowe Ynne Daies Of Yore // The Ex-Classics Web Site. URL: http://www.exclassics.com/rowley/rowl18.htm

7. Th e Complete Poetical Works of Thomas Chatterton: in 2 vols / ed. H.D. Roberts. London: George Routledge and sons; New York: E.P. Dutton \& Co, 1906. Vol. 2. 222 p.

8. Macpherson J. The Poems of Ossian and Related Works / ed. H. Gaskill. Edinburgh: Edinburgh University Press, 2006. 573 p.

9. The Letters of John Keats / ed. H.B. Forman. London: Reeves \& Turner, 1895. 522 p. 